Proc. Estonian Acad. Sci. Biol. Ecol., 2003, 52, 3, 305-318

\title{
Concentrations of mercury and cadmium in some coastal fishes from the Finnish and Estonian parts of the Gulf of Finland
}

\begin{abstract}
Heinz-Rudolf Voigt
Department of Limnology and Environmental Protection, P.O.Box 62, Infocenter (514), FIN 00014 University of Helsinki-Helsingfors, Finland; heinz-rudolf.voigt@ helsinki.fi

Received 7 January 2003, in revised form 31 March 2003

Abstract. Concentrations of mercury and cadmium were analysed from Clupea harengus membras L., Sprattus sprattus sprattus L., Osmerus eperlanus L., Zoarces viviparus L., Gasterosteus aculeatus L., Myoxocephalus quadricornis L., M. scorpius L., Cyclopterus lumpus L., Perca fluviatilis L., Platichthys flesus L., and Psetta maxima L. sampled from coastal waters of the Finnish and Estonian parts of the Gulf of Finland: the Tvärminne Archipelago at Hanko-Hangö and the Helsinki region in Finland, and from the bays of Muuga, Käsmu, and Kunda in Estonia. The concentrations of $\mathrm{Hg}$ in muscle tissue, liver, and gonads were the highest in predatory species, e.g. M. scorpius, $P$. fluviatilis, and $P$. maxima regardless of the sampling area, and for most species, except $C$. harengus membras and C. lumpus, the concentrations were higher in muscle tissue than in liver. A statistically significant negative correlation between the condition factor $(K)$ and the concentration of $\mathrm{Hg}$ in muscle tissue was found for $O$. eperlanus and P. flesus from Tvärminne. The highest concentrations of Cd were recorded from the liver of $P$. flesus, $C$. harengus membras, and $P$. fluviatilis from Tvärminne, and $Z$. viviparus from Muuga and Kunda. The results show a weak, although not statistically significant, decrease of $\mathrm{Hg}$ in muscle tissue, but a pronounced decrease of $\mathrm{Cd}$ in liver by the present time compared to the 1970s-80s. Except $\mathrm{Hg}$ in the muscle tissue of P. fluviatilis from the Helsinki area and in two individuals of $M$. scorpius from Tvärminne, the concentrations of both metals studied did not exceed either the Finnish $\left(\mathrm{Hg}=0.5 \mathrm{mg} \mathrm{kg}^{-1}, \mathrm{Cd}=0.1 \mathrm{mg} \mathrm{kg}^{-1}\right.$ f.wt) or the Estonian $\left(\mathrm{Hg}=0.5, \mathrm{Cd} 0.2 \mathrm{mg} \mathrm{kg}^{-1}\right.$ f.wt) maximum permissible levels for fish for human consumption.
\end{abstract}

Key words: mercury, cadmium, coastal fishes, Gulf of Finland, Baltic Sea.

\section{INTRODUCTION}

Prior to 1992 environmental monitoring of harmful substances, for example heavy metals such as mercury and cadmium, in Baltic fish focused on mainly two open sea species: Baltic herring (Clupea harengus membras L.) and cod (Gadus morhua callaris L.). From both of these analyses were made of homogenates of 
twenty individuals (of the same size, indicating the same age, and of the same sex, female) in total for each sample (ICES, 1977, 1979; HELCOM, 1980, 1984). Further recommendations included similar analyses of mainly muscle tissue of open sea Baltic sprat (Sprattus sprattus sprattus L.) and flounder (Platichthys flesus L.) (ICES, 1979; HELCOM, 1984, 1988). Near shore coastal fishes, pelagic and demersal, for example smelt (Osmerus eperlanus L.), eelpout (Zoarces viviparus L.), three-spined stickleback (Gasterosteus aculeatus L.), four-horn sculpin (Myoxocephalus quadricornis L.), bull-rout (M. scorpius L.), lumpsucker (Cyclopterus lumpus L.), perch (Perca fluviatilis L.), flounder, and turbot (Psetta maxima L.) were seldom used for this kind of monitoring, as the monitoring of coastal water was considered "a national obligation" (HELCOM, 2002). Such data, however, would most likely reflect the conditions of the environment of coastal fishes, as the open sea species reflect the conditions of their environment (Voigt, 1994, 2000). In 1992 Cooperative Monitoring in the Baltic Marine Environment (COMBINE) was instituted. The recommendations included among others that coastal fish species such as viviparous blenny or eelpout, perch, and flounder should be monitored (HELCOM, 2002). According to this programme the monitoring in Finland and Estonia now includes muscle tissue and liver of open sea herring for $\mathrm{Hg}$ and $\mathrm{Cd}$ analyses, and muscle tissue of open sea cod and near shore perch for $\mathrm{Hg}$ analyses.

Such monitoring is of great significance for decision-making regarding health aspects in connection with fish as food for both human and animal consumption, and it also contributes to the description of the environmental state of the Baltic Sea. So far the monitoring results indicate a distinct decrease in the concentrations of mercury since the 1970s in the muscle tissue of (young, open sea) Baltic herring from the gulfs of Bothnia and Finland (Perttilä et. al., 1982; Haahti, 1991; SVT, 1994; Ympäristö, 1998, 2001; Roots \& Simm, 2002). On the contrary, the level of cadmium in the liver of herring from mainly the Baltic Proper showed an increase (HELCOM, 1998, 2001). They do not, however, contribute notably to the description of the coastal environment, or describe the specific situation of metal contamination within the fish themselves. Both these aspects are considered in the present study. Thus, the aim of the study was to collect and present available data on $\mathrm{Hg}$ and $\mathrm{Cd}$ concentrations in fish in order to find some guidelining mean values for the concentrations of these extremely toxic metals in coastal fishes from both the northern and southern parts of the Gulf of Finland.

\section{MATERIAL AND METHODS}

The fish were sampled during the autumn season (late August-mid-October) in 1994-2001 by trawl and gillnets from some selected sampling stations at the Finnish and Estonian coasts of the Gulf of Finland: the Tvärminne Archipelago off the Hanko-Hangö Peninsula and the Helsinki region in Finland and from Muuga, Käsmu, and Kunda bays in Estonia. The Tvärminne Archipelago at the Zoological Station of the University of Helsinki-Helsingfors is a well-studied 
Finnish coastal area, influenced only by a steel and iron factory with known impacts on the surrounding environment. The miscellaneous effluents from the Helsinki region are suspected to have an impact on the coastal waters in this region, as are the effects from the construction works for the new harbour complex for Tallinn in Muuga Bay. Käsmu and Kunda bays are both regarded as non-polluted reference areas.

All fish were measured (total length, cm; TL) and weighed (total weight, g) fresh prior to frozen storage $\left(-18^{\circ} \mathrm{C}\right)$ for further investigations and metal analysis. The condition factor $(K)$ was calculated for all fish according to the formula: $K=100 \times$ total weight of fish in $\mathrm{g} /(\text { total length of fish in } \mathrm{cm})^{3}$ (Busacker et al., 1990). For the metal analyses liver, kidneys, gonads, and muscle tissue from the dorsoventral part of the fish were prepared.

Mercury was analysed according to the cold vapour atomic spectrophotometric method (CVAAS) as described in AOAC (1970), modified for analysis of fish by Uthe et al. (1970) and Kivalo et al. (1974) by using the Coleman Mercury Analyzer System (MAS-50B). The results of the analyses for mercury are all expressed in $\mathrm{mg} \mathrm{kg}^{-1}$, fresh weight (f.wt).

Cadmium was analysed according to the electrothermal atomic absorption spectrometry (ETAAS) using a Varian SpectrAA-400 equipped with a graphite furnace GTA-96, as described by Lodenius et al. (2002). The results for cadmium analyses are primarily given in $\mathrm{mg} \mathrm{kg}^{-1}$, dry weight (d.wt), but for comparisons the means may be transformed into $\mathrm{mg} \mathrm{kg}^{-1}$ f.wt by using calculated conversion factors for each organ and tissue of the fish species in question. For the muscle, liver, and gonads of sprat and herring these factors are $0.20,0.35,0.27$, smelt $0.19,0.25,0.22$, eelpout $0.19,0.26,0.20$, stickleback $0.21,0.19$, sculpins 0.20 , $0.33,0.18$, lumpsucker $0.22,0.40,0.22$, perch $0.21,0.26,0.19$, flounder and turbot $0.20,0.33,0.20$, respectively. For kidneys of all fish species the factor is 0.19 . All samples were analysed in duplicate, and the accuracy was assessed using blanks (5 per each sequence of 40 samples) and reference materials CRM-422 cod muscle (Quevauviller et al., 1993), for which the certificate values compared to the obtained ones were: $\mathrm{Hg}=0.559$ (SD 0.016) and 0.55 (SD 0.035), and $\mathrm{Cd}=0.018$ (SD 0.003) and 0.017 (SD 0.002) $\mathrm{mg} \mathrm{kg}^{-1}$ f.wt, respectively. The statistical treatment of the material includes the Shapiro-Wilk test for normality, the Pearson or Spearman rank tests for correlations, and the two-sample $t$-test or the Wilcoxon rank sum test for differences.

\section{RESULTS}

The mean total length (TL), the mean calculated condition factor $(K)$, and the results from the analyses of mercury and cadmium are presented in Tables 1 and 2 , respectively. The means of TL for sprat, herring, and smelt from Tvärminne and Helsinki, eelpout, three-spined stickleback, lumpsucker, and perch from Tvärminne and Käsmu, and flounder from Tvärminne and Kunda are all of the same order of magnitude within the species, indicating equality in age. 
The $K$ value calculated for smelt, eelpout, three-spined stickleback, four-horn sculpin, and perch is of the same order of magnitude within the species, regardless of the sampling area, in contrast to $K$ calculated for herring, bull-rout, lumpsucker, and flounder. A negative correlation was found between $K$ and the $\mathrm{Hg}$ concentration in the muscle tissue of herring from Kunda, smelt from Tvärminne and Kunda, eelpout from Tvärminne, Muuga and Kunda, three-spined stickleback from Tvärminne, flounder from Tvärminne and Kunda, and turbot from Tvärminne. However, these correlations were statistically significant only for smelt and flounder, both from Tvärminne, (Pearson test; $r=-0.40, p=0.0000$, and $r=-0.30, p=0.0075$, respectively). This correlation was insignificantly positive for sprat and herring from Tvärminne, three-spined stickleback from Kunda, four-horn sculpin and bull-rout from Tvärminne and Käsmu, lumpsucker from Tvärminne and Käsmu, and perch from Tvärminne, Helsinki, and Käsmu.

The highest concentrations of $\mathrm{Hg}$ in muscle tissue were recorded from pure predatory species, for example perch, bull-rout, and turbot, while omnivorous species such as four-horn sculpin showed considerably lower concentrations. In pelagic, benthopelagic, benthic, and short-lived species, for example sprat, herring, smelt, flounder, eelpout, and three-spined stickleback, the concentrations were even lower and from lumpsucker they were among the lowest.

The highest concentrations of $\mathrm{Hg}$ in liver were likewise recorded from the predatory species, for example bull-rout and perch, but for herring and smelt the concentrations exceeded the values recorded for four-horn sculpin, flounder, turbot, and eelpout (the diminutive livers of herring from Kunda were analysed all together as one single sample in contrast to the individual analyses of livers of the other species). There were no significant differences between the sexes for the concentrations of $\mathrm{Hg}$ in muscle tissue and liver.

For most species the concentrations of $\mathrm{Hg}$ were higher in muscle tissue than in liver and gonads. For herring and lumpsucker, however, the opposite was observed in most cases. The means of the individually calculated ratios for $\mathrm{Hg}$ in muscle tissue to $\mathrm{Hg}$ in liver appeared to be of the same order of magnitude for herring, smelt from Finnish waters, eelpout from Estonian waters, four-horn sculpin, and perch, while there was a considerable distinction depending on water body for flounder, eelpout, and smelt. The highest ratio was calculated for bull-rout.

In the gonads of both sexes the concentrations of $\mathrm{Hg}$ were all lower than in liver. The highest concentrations of $\mathrm{Hg}$ in gonads were recorded for bull-rout, followed by four-horn sculpin and perch, in which the concentrations were of the same order of magnitude. In all other species they did not exceed the low value of $0.05 \mathrm{mg} \mathrm{kg}^{-1}$ f.wt. For all species the concentrations of mercury were in most cases slightly higher in the testes than in the ovaries.

The means of TL for sprat, herring, eelpout, three-spined stickleback, perch, and flounder were of the same order of magnitude regardless of water body, but they differed notably for smelt and four-horn sculpin. For $K$ the calculated means were of the same order of magnitude for herring, eelpout, three-spined stickleback, and four-horn sculpin within the species, but for smelt and flounder this difference is considerable. With the exception of three-spined stickleback, for 


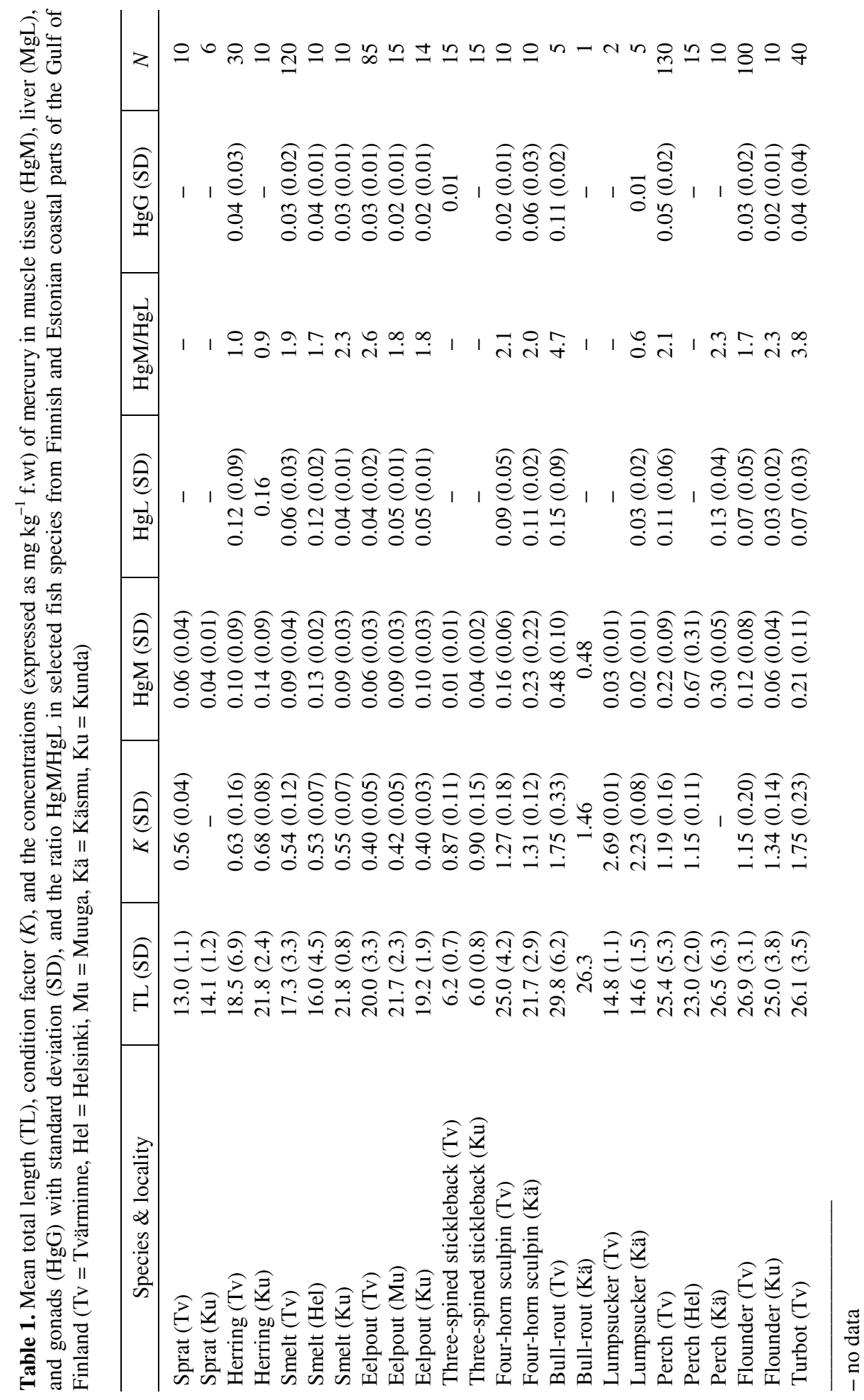




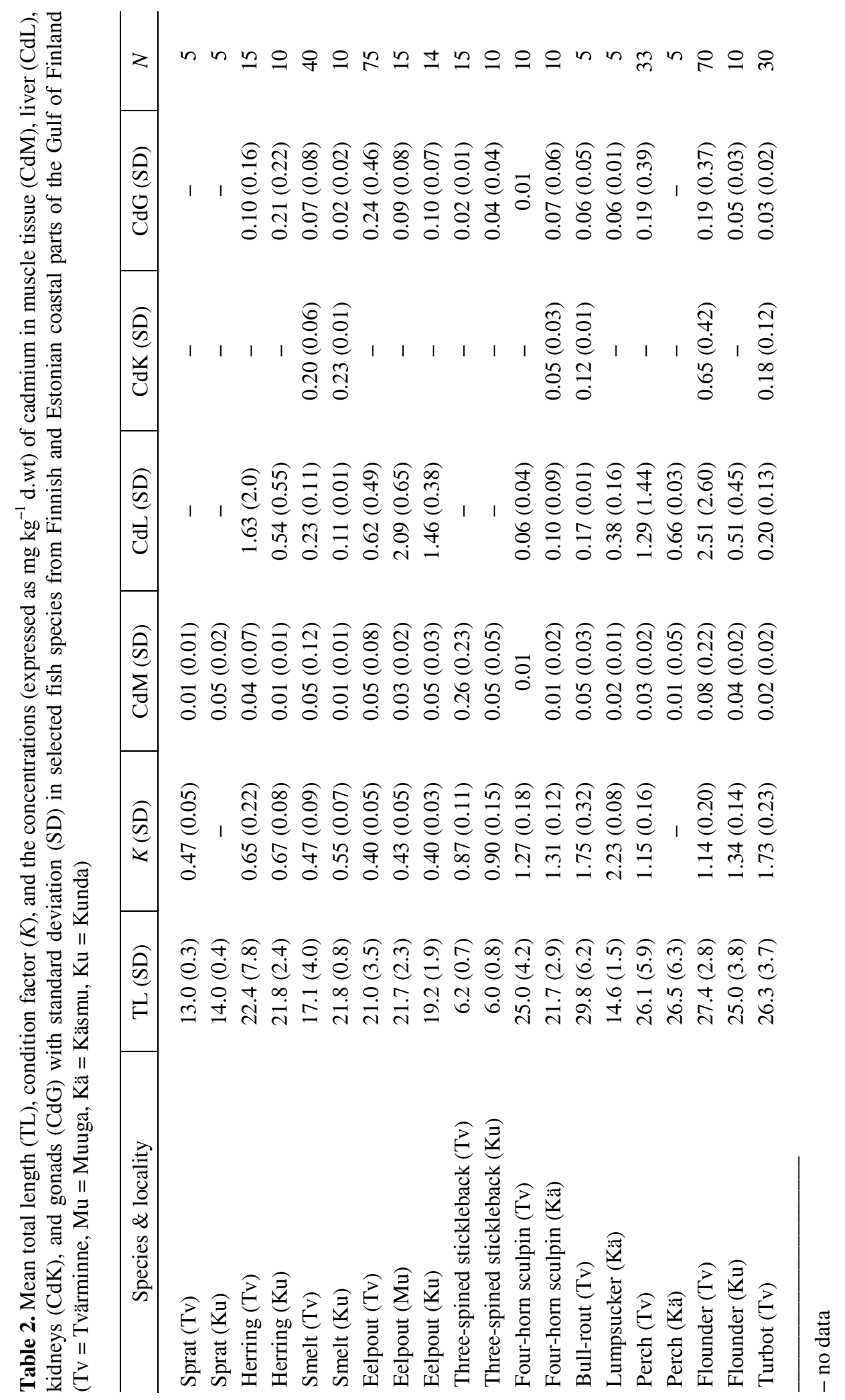


which Cd was analysed from the whole fish ("in toto") excluding the gonads, and not from muscle tissue or liver separately, the mean values for $\mathrm{Cd}$ in muscle tissue were all below $0.1 \mathrm{mg} \mathrm{kg}^{-1} \mathrm{~d}$.wt. The highest concentrations, which exceeded $0.05 \mathrm{mg} \mathrm{kg}^{-1}$ d.wt, were calculated for flounder from Tvärminne. Flounder from Tvärminne showed also the highest concentrations of $\mathrm{Cd}$ in liver, followed by eelpout from Muuga, herring from Tvärminne, eelpout from Kunda, perch from Tvärminne and Käsmu, eelpout from Tvärminne, and herring and flounder from Kunda, in all which the mean concentrations of $\mathrm{Cd}$ exceeded the value of $0.50 \mathrm{mg} \mathrm{kg}^{-1} \mathrm{~d}$.wt. Also the highest concentrations of $\mathrm{Cd}$ in kidneys were recorded from flounder from Tvärminne. There were no significant differences between the sexes for the concentrations of $\mathrm{Cd}$ in muscle tissue, liver, and kidneys.

In the gonads of both sexes the highest concentrations of $\mathrm{Cd}$ were recorded from eelpout from Tvärminne, herring from Kunda, and from perch and flounder from Tvärminne. As for $\mathrm{Hg}$, the concentrations of $\mathrm{Cd}$ were in most cases higher in the testes than in the ovaries.

All the studied fish appeared to be healthy. There were no visible defects on either liver or kidneys of the fish investigated.

\section{DISCUSSION}

As all the material for the study was sampled from the mid-1990s until 2001, the results from the analyses of $\mathrm{Hg}$ and $\mathrm{Cd}$ for each species are comparable for the aspect of time. Concerning the investigation area, the Gulf of Finland, these results only reflect the situation at the different sampling stations. However, they may have some contributional value for a description of the environmental situation of the entire water body, especially if corresponding data from previous periods are available. For most of the species studied such data are rather scarce. Still, for muscle tissue of some species from Tvärminne the concentrations of $\mathrm{Hg}$ $\left(\mathrm{mg} \mathrm{kg}^{-1}\right.$ f.wt) are available. In the 1970 s these were for smelt $0.13, \mathrm{SD}=0.04$, $N=210$; four-horn sculpin $0.22, \mathrm{SD}=0.05, N=7$; flounder $0.15, \mathrm{SD}=0.08$, $N=17$ (Voigt, 2002a). Compared to the corresponding data in Table 1 they indicate a slight decreasing tendency, which however is not statistically significant (two-sample $t$-test, $p=0.061,0.251$, and 0.293, respectively). A decade later, in 1988, the corresponding values for flounder off Hanko-Hangö were: $\mathrm{HgM}=0.14$, $\mathrm{SD}=0.07, N=51$ (Voigt et al., 1994). For the other species in Table 1 data of only means from the literature may be used for comparison, but such corresponding data from the same sampling stations are scarce and they have only a limited significance. A collection of available means of the concentration of $\mathrm{Hg}$ in muscle tissue of some investigated fish species from the Gulf of Finland is presented in Table 3.

Except the obvious distinction between the low $\mathrm{Hg}$ values for fish from the open sea compared to the higher values for inshore fish, these means support the assumption of a decrease in $\mathrm{Hg}$ in muscle tissue of fish in time since the 1970s. 
Table 3. Mean concentrations of mercury in muscle tissue $(\mathrm{HgM})$, expressed as $\mathrm{mg} \mathrm{kg}^{-1}$ f.wt, of selected fish species from the Gulf of Finland according to data from the literature

\begin{tabular}{|c|c|c|c|c|}
\hline Fish species & $\mathrm{HgM}$ & $N$ & Area and period & Author \\
\hline Sprat & 0.02 & 20 & Off Hanko, open sea, 1974 & Voipio et al., 1977 \\
\hline Sprat & 0.09 & 20 & Off Kotka, open sea, 1974 & Voipio et al., 1977 \\
\hline Sprat & 0.12 & - & Tallinn Bay 1975 & Ott \& Jankovski, 1980 \\
\hline Sprat & 0.20 & - & Narva Bay 1975 & Ott \& Jankovski, 1980 \\
\hline Herring & 0.08 & 8 & Off Kotka 1967 & Sjöblom, 1969 \\
\hline Herring & 0.02 & 20 & Off Hanko, open sea, 1974 & Voipio et al., 1977 \\
\hline Herring & 0.04 & 20 & Off Kotka, open sea, 1974 & Voipio et al., 1977 \\
\hline Herring & 0.02 & 100 & Off Hanko, open sea, 1979 & Tervo et al., 1980 \\
\hline Herring & 010 & - & Helsinki area 1967 & Häsänen \& Sjöblom, 1968 \\
\hline Herring & 0.04 & 30 & $\begin{array}{l}\text { Off Helsinki, open sea, } \\
\text { 1979-82 }\end{array}$ & Tervo, 1983 \\
\hline Herring & 0.04 & 100 & Off Kotka, open sea, 1979 & Tervo et al., 1980 \\
\hline Herring & 0.01 & 20 & Off Hanko, open sea, 1982-86 & Tervo, 1987 \\
\hline Herring & 0.04 & 40 & Off Kotka, open sea, 1982-86 & Tervo, 1987 \\
\hline Herring & 0.12 & 11 & Tallinn Bay 1977 & Ott et al., 1982 \\
\hline Herring & 0.04 & - & Tallinn Bay 1998 & Pachel et al., 2001 \\
\hline Herring & 0.10 & - & Narva Bay 1975 & Ott \& Jankovski, 1980 \\
\hline Smelt & 0.10 & - & Helsinki area 1967 & Häsänen \& Sjöblom, 1968 \\
\hline Four-horn sculpin & 0.14 & 3 & Off Hanko 1962 & Nuorteva \& Häsänen, 1971 \\
\hline Four-horn sculpin & 0.61 & 1 & Ahvenkoski 1968 & Sjöblom, 1969 \\
\hline Perch & 0.63 & 8 & Helsinki area 1967 & Häsänen \& Sjöblom, 1968 \\
\hline Perch & 0.62 & 9 & Ahvenkoski 1975-76 & Kokko \& Lindell, 1988 \\
\hline Perch & 0.57 & 10 & Ahvenkoski 1981 & Kokko \& Lindell, 1988 \\
\hline Perch & 0.64 & 5 & Kotka area 1976 & Lakomaa \& Häsänen, 1978 \\
\hline Perch & 0.44 & 8 & Kotka area $1980-81$ & Kokko \& Lindell, 1988 \\
\hline Perch & 0.15 & - & Paldiski Bay 1978 & Ott \& Jankovski, 1980 \\
\hline Flounder & 0.03 & 20 & Off Hanko 1974 & Voipio et al., 1977 \\
\hline
\end{tabular}

The information available on $\mathrm{Cd}$ that could be used for making temporal comparisons (Table 4) is even scarcer than in $\mathrm{Hg}$.

To compare the values in Table 4 with the corresponding data in Table 2 they have to be converted from fresh weight to dry weight by means of the previously presented converting factors; for example, the mean value for $\mathrm{Cd}$ in the liver of herring from Kunda $=0.54 \mathrm{mg} \mathrm{kg}^{-1}$ d.wt $($ Table 2) $\times 0.35$ (conversion factor for liver of herring) $=0.189 \mathrm{mg} \mathrm{kg}^{-1}$ f.wt. This value is considerably lower than the corresponding one in herring from Kunda in the 1980s (Table 4). The decrease is notable also for $\mathrm{Cd}$ in the liver of eelpout from Tvärminne $\left(0.161 \mathrm{mg} \mathrm{kg}^{-1}\right.$ f.wt) 


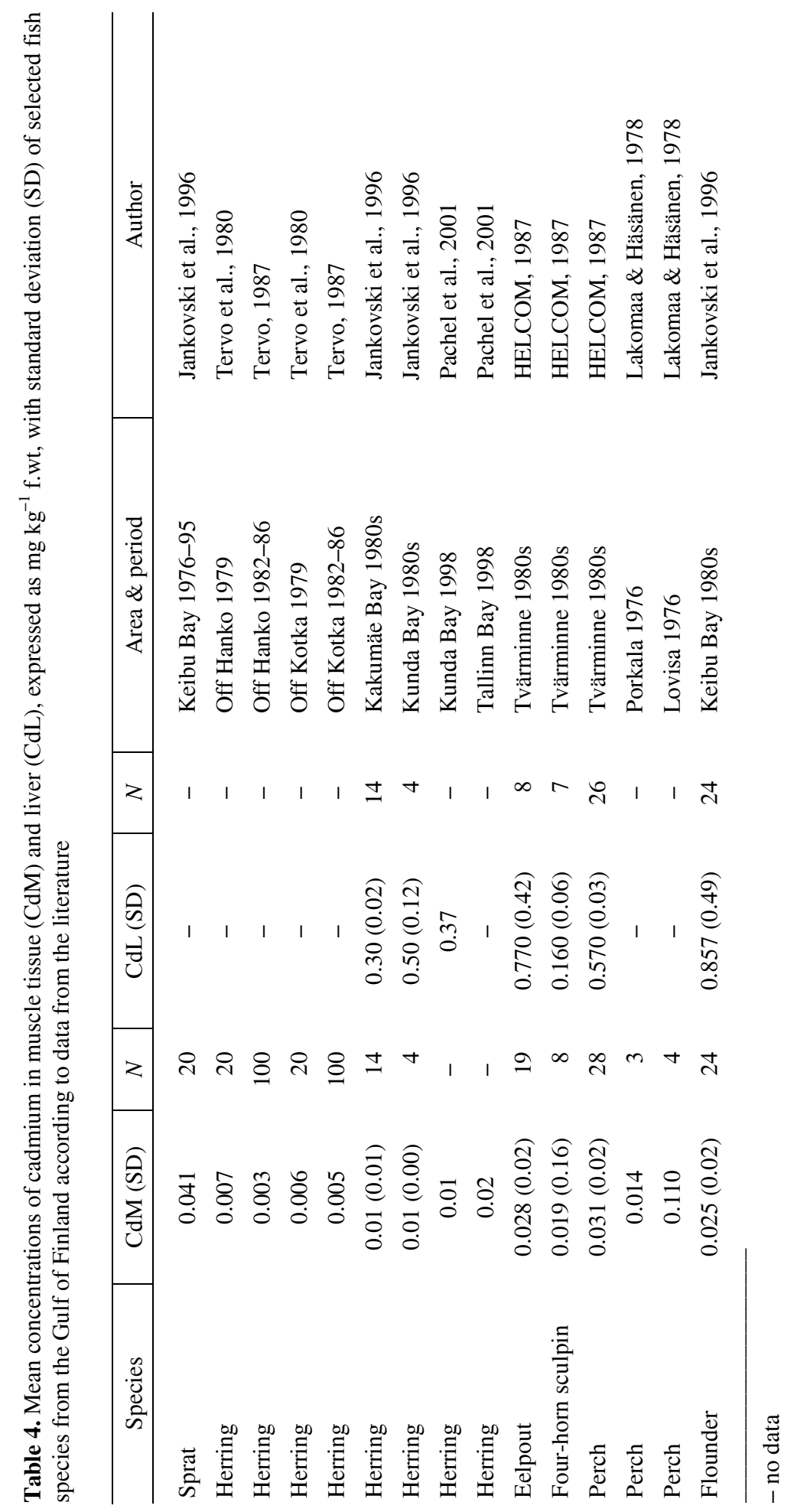


as well as for four-horn sculpin (0.020), and perch $\left(0.335 \mathrm{mg} \mathrm{kg}^{-1} \mathrm{f}\right.$.wt). The highest calculated mean for $\mathrm{Cd}$ in the liver of flounder from Tvärminne $\left(0.828 \mathrm{mg} \mathrm{kg}^{-1} \mathrm{f}\right.$.wt $)$ is of the same order of magnitude as for $\mathrm{Cd}$ in the liver of flounder from Keibu Bay $\left(0.857 \mathrm{mg} \mathrm{kg}^{-1}\right.$ f.wt) in the 1980s (Jankovski et al., 1996).

In the gonads of herring from Kunda a mean concentration of $\mathrm{Cd}=0.21 \mathrm{mg} \mathrm{kg}^{-1}$ f.wt (SD 0.11) was reported for the 1980s (Jankovski et al., 1996), which also by far exceeds the corresponding value from the 1990s $\left(0.057 \mathrm{mg} \mathrm{kg}^{-1}\right.$ f.wt., Table 2). As a whole, there obviously is a distinct decrease in the concentrations of $\mathrm{Cd}$ in muscle tissue and especially in liver in time.

The main entrances of $\mathrm{Cd}$ into the fish are by the food through the alimentary canal (Eisler, 1981) and from the surrounding water by the gills (Karbe et al., 1987). From these organs it is transported to mainly liver and kidneys by the blood (Reichenbach-Klinke, 1978, 1980; Halsband et al., 1984). The Cd binding proteins, metallothioneines, concentrate the amount of accessible $\mathrm{Cd}$ in these organs (Kruse, 1981; Eisler, 1985), from which the excretion depends on the amount of metallothioneines (Hofer \& Lackner, 1995). The concentration of Cd in the kidneys thus reflects both the accumulation and the excretion of the metal in the fish. As $\mathrm{Cd}$ is not accumulated in the muscle tissue it is suggested that the concentrations of $\mathrm{Cd}$ in this tissue only reflect the actual concentrations of $\mathrm{Cd}$ in the blood during the transportation (Voigt, 2002b). This also explains the unreliability of muscle tissue for environmental monitoring (HELCOM, 1987a; ICES, 1988). Still, Cd concentration in muscle tissue contributes to the description of the contamination of the whole fish. For further evaluations of the accumulation and the effects of bound $\mathrm{Cd}$ upon fish, information on the corresponding concentrations of zinc is essential due to the high affinity of the metallothioneines for both metals, which may act either synergetically or antagonistically in the liver and kidneys of fish (Reichenbach-Klinke, 1980; Eisler, 1993).

\section{CONCLUSIONS}

The concentrations of $\mathrm{Hg}$ are higher in the pure predatory species such as adult bull-rout, perch ( $>20 \mathrm{~cm} \mathrm{TL}$ ), and turbot, as previously stated for Baltic fishes (HELCOM, 1987b), than in the omnivorous species, for example four-horn sculpin. For eelpout and smelt, which are partly benthophagous, and the pelagic plankton feeding clupeids, sprat and herring, the levels are even lower. Thus the forage habit also reflects the mercury contamination of fishes.

The correlations between $K$ and $\mathrm{Hg}$ in muscle tissue of most species investigated (as shown also for flounder from the Åland Islands; Voigt, 2002b) require more attention in future studies.

No significant decreasing trends of $\mathrm{Hg}$ in time were observed for the concentrations in the muscle tissue of the investigated fishes in contrast to the obvious decrease of $\mathrm{Cd}$ in the liver. Thus the results for $\mathrm{Cd}$ in the liver of these 
coastal fishes from the Gulf of Finland are not in agreement with the findings from fishes from the Baltic proper (HELCOM, 1998).

As there are notable differences between the sampling areas for the metal concentrations in some of the investigated species, for example four-horn sculpin, perch, and flounder, the results may be used mainly for the assessments of the relevant sampling areas, but not for the entire Gulf of Finland.

By using individual samples of certain tissues and organs (muscle, liver, kidneys, gonads) from each fish separately not only the present level of contamination but also the natural distribution, and even the effects of the actual harmful substances in question within the fish, may be detected according to the procedure. All this contributes to better knowledge of heavy metal contamination in fish in natural conditions.

With a few exceptions for bull-rout and perch, the concentrations of $\mathrm{Hg}$ and $\mathrm{Cd}$ detected do not exceed the maximum permissible levels for fish as food either in Estonia and Finland or in the European Union (European Commission, 1993; Tahvonen \& Kumpulainen, 1998; Vabariigi Valitsus, 2000).

\section{ACKNOWLEDGEMENTS}

Inestimable support and assistance was provided by my colleagues Martin Lodenius, Heikki Tervahattu, and Esa Tulisalo, all three from the Department of Limnology and Environmental Protection at the University of HelsinkiHelsingfors (Finland); Ott Roots from the Information Centre of the Estonian Ministry of Environment, Tallinn; Mart Kangur and Alexei Turovski, both from the Estonian Institute of Marine Research, Tallinn; and Markus Vetemaa from the Department of Zoology and Hydrobiology of the University of Tartu (Estonia).

The study was financed partly by Nordisk Forskerutdanningsakademi (NorFA), Oslo, (Ref. No. 947800100) and by the Oskar Öflund Foundation, Helsingfors, Finland.

\section{REFERENCES}

AOAC. 1970. Official Methods of Analysis. 11th. edn. Association of Official Analytical Chemists, Washington, DC.

Busacker, G. P., Adelman, I. R. \& Goolish, E. M. 1990. Growth. In Methods for Fish Biology (Schreck, C. B. \& Moyle, P. B., eds.), pp. 363-387. American Fisheries Society, Bethesda, Maryland, USA.

Eisler, R. 1981. Trace Metal Concentrations in Marine Organisms. Pergamon Press, New York.

Eisler, R. 1985. Cadmium hazards to fish, wildlife, and invertebrates: a synoptical review. U.S. Wildlife Service Contaminant Hazards Rev. Rep., 2, 1-46.

Eisler, R. 1993. Zink hazards to fish, wildlife, and invertebrates: a synoptic review. US Wildlife Service Contaminant Hazards Rev. Rep., 26, 1-106.

European Commission. 1993. Commission decision 19.5.1993 No 93/352/EEC. Off. J. EC, L 144, 23-24. 
Haahti, H. 1991. Concentrations of harmful substances in fish in the northern Baltic. Mem. Soc. Fauna Flora Fenn., 67(1), 15-20.

Halsband, E., Halsband, I. \& Pump, H. 1984. Die Wirkung von Cadmium auf das Blutbild, die Organe und das Skelettsystem von Forellen sowie die Beeinflussung durch kristallisiertes Dihydrotachysterol und Calcium. Fisch Umwelt, 13, 139-177.

Häsänen, E. \& Sjöblom, V. 1968. Kalojen elohopeapitoisuus Suomessa vuonna 1967. Suomen Kalatalous-Finlands Fiskerier, 36, 1-24.

HELCOM (Helsinki Commission). 1980. Guidelines for the Baltic Monitoring Programme for the First Stage. Baltic Marine Environment Protection Commission, Helsinki.

HELCOM (Helsinki Commission). 1984. Guidelines for the Baltic monitoring programme for the second stage. Balt. Sea Environ. Proc., 12.

HELCOM (Helsinki Commission). 1987a. First periodic assessment of the state of the marine environment of the Baltic Sea area, 1980-1985; background document. Balt. Sea Environ. Proc., 17B.

HELCOM (Helsinki Commission). 1987b. Progress reports on cadmium, mercury, copper and zinc. Balt. Sea Environ. Proc., 24.

HELCOM (Helsinki Commission). 1988. Guidelines for the Baltic monitoring programme for the third stage. Part C. Harmful substances in biota and sediments. Balt. Sea Environ. Proc., 27C.

HELCOM (Helsinki Commission). 1998. Final report on implementation of the 1988 ministerial declaration. Balt. Sea Environ. Proc., 71.

HELCOM (Helsinki Commission). 2001. Environment of the Baltic Sea area 1994-1998. Balt. Sea Environ. Proc., 82A.

HELCOM (Helsinki Commission). 2002. Manual for marine monitoring in the COMBINE programme of HELCOM. http://www.helcom.fi/Monas/CombineManual12/PartA/Introduction.htm

Hofer, R. \& Lackner, R. 1995. Fischtoxikologie - Theorie und Praxis. G. Fischer, Stuttgart, New York.

ICES (International Council for Exploration of the Seas). 1977. Studies of the pollution of the Baltic Sea. Coop. Res. Rep., 63.

ICES (International Council for Exploration of the Seas). 1979. Report of the ICES advisory committee on marine pollution, 1978. Coop. Res. Rep., 84.

ICES (International Council for Exploration of the Seas). 1988. Results of 1985 baseline study of contaminants in fish and shellfish. Coop. Res. Rep., 151.

Jankovski, H., Simm, M. \& Roots, O. 1996. Harmful substances in the Gulf of Finland. EMI (Estonian Marine Institute) Rep. Ser., 4.

Karbe, L., Bias, R. \& Borchardt, T. 1987. Aufnahmekinetik und Anreicherung von Blei und Kadmium in Muscheln und Fischen. In Bioakkumulation in Nahrungsketten (Lilleund, K., ed.), pp. 219-225. Deutsche Forschungsgemeinschaft Forschungsbericht, VHC, Weinheim.

Kivalo, P., Visapää, A. \& Bäckman, R. 1974. Atomic absorption determination of mercury in fish using the Coleman MAS-50 mercury analyzer. Anal. Chem., 46, 1814-1817.

Kokko, H. \& Lindell, L. 1988. Kalojen elohopeapitoisuuksia Kymen läänin ja Ruotsinpyhtään kunnan alueilla vuosina 1967-1986. Vesi- ja ympäristöhallituksen Monistesarja, 81.

Kruse, R. 1981. Erfahrungen bei der Spurenanalyse von Quecksilber, Blei und Cadmium in Fischen unter Anwendung moderner Bestimmungsverfahren. Fisch Umwelt, 10, 19-32.

Lakomaa, E.-L. \& Häsänen, E. 1978. Eräiden myynnissä olevien kalalajien elohopea-ja kadmiumpitoisuuksia. Elinkeinohallituksen Kuluttaja-asian osaston Julkaisuja, A1, 1-12. Helsinki.

Lodenius, M., Soltanpour-Gargari, A., Tulisalo, E. \& Henttonen, H. 2002. Effects of ash application on cadmium concentration in small mammals. J. Environ. Qual., 31, 188-192.

Nuorteva, P. \& Häsänen, E. 1971. Observations on the mercury content of Myoxocephalus quadricornis L. in Finland. Ann. Zool. Fenn., 8(3), 331-335.

Ott, R. \& Jankovski, H. 1980. Mercury in the southern part of the Gulf of Finland. Finn. Mar. Res., 247, 68-72. 
Ott, R., Jankovski, H., Kikas, U., Lipre, E., Paju, A., Põder, T. \& Žagel, K. 1982. Elavhõbedasisaldus Eesti NSV rannikumere vees ja organismides. In Eesti rannikumere kaitse (Järvekülg, A., ed.), pp. 93-100. Valgus, Tallinn.

Pachel, K., Narusk, M., Ristkok, H., Reap, A., Ljamtsev, A., Roots, O., Lips, U. \& Simm, M. 2001. Water. In State of Environment in Estonia on the Threshold of 21 Century, pp. 41-70. Estonian Environment Information Centre, Tallinn.

Perttilä, M., Tervo, V. \& Parmanne, R. 1982. Heavy metals in Baltic herring and cod. Mar. Pollut. Bull., 13(11), 391-393.

Quevauviller, P., Imbert, J. L., Wagstaffe, P. J., Kramer, G. N. \& Griepnik, B. 1993. Reference materials, ESC-EEC-EAEC. Report EUR 14557 EN. Commission of the European Communities BCR Information, 1-64. Brussels-Luxembourg.

Reichenbach-Klinke, H.-H. 1978. Zur Ökologie der Schwermetallanreicherung in Fischen. Fisch Umwelt, 6, 7-11.

Reichenbach-Klinke, H.-H. 1980. Krankheiten und Schädigungen der Fische. 2. Aufl. G. Fischer, Stuttgart, New York.

Roots, O. \& Simm, M. 2002. Heavy metals in the Baltic fish and molluscs. In SECOTOX 2002 Trends and Advances in Environmental Chemistry and Ecotoxicology. Book of Abstracts (Holoubek, I., ed.), pp. 58-60. 7th Meeting of the Central and Eastern European Section of RECETOC \& TOCOCEN Association, Brno.

Sjöblom, V. 1969. Kvicksilverhalten i fisk i Finland. Nord. Hyg. Tidskr., 1(2), 37-53.

SVT (Suomen Virallinen Tilasto - Official Statistics of Finland). 1994. Ympäristötilasto - Environment Statistics. Ympäristö-Environment, 3. Helsinki.

Tahvonen, R. \& Kumpulainen, J. T. 1998. Lead, cadmium and mercury. In Safety and Nutrional Quality of Finnish Foods (Kumpulainen, J. T., ed.), pp. 15-26. Gummerus, Jyväskylä.

Tervo, V. 1983. Raskasmetallipitoisuudet silakassa. Meri, 12, 94-97.

Tervo, V. 1987. Concentrations of metals in fish and benthic invertebrates in the Gulf of Finland and in the Gulf of Bothnia during 1982-1986. ICES C.M. 1987/E 20, 1-15.

Tervo, V., Erkomaa, K., Sandler, H., Miettinen, V., Parmanne, R. \& Aro, E. 1980. Contents of metals and chlorinated hydrocarbons in fish and benthic invertebrates in the Gulf of Bothnia and in the Gulf of Finland. Aqua Fenn., 10, 42-57.

Uthe, J. F., Armstrong, F. A. J. \& Stainton, M. P. 1970. Mercury determination in fish samples by wet digestion and flameless atomic absorption spectrophotometry. J. Fish. Res. Board Can., 27(4), 805-811.

Vabariigi Valitsus. 2000. Määrus 12.1.2000 Nr 14. RTI, 6, 38.

Voigt, H.-R. 1994. Fish surveys in the Väike Väin strait between the Islands of Saaremaa and Muhu, western Estonia. Proc. Estonian Acad. Sci. Ecol., 4, 128-135.

Voigt, H.-R. 2000. Heavy metal and organochlorine levels in coastal fishes from the Väike Väin Strait, western Estonia, in high summers of 1993-94. Proc. Estonian Acad. Sci. Biol. Ecol., 49, 335-343.

Voigt, H.-R. 2002a. Tvärminnefiskens kvicksilverhalter. Fiskeritidskr. Finl., 46(4), 15-17.

Voigt, H.-R. 2002b. Concentrations of cadmium in flounder (Platichthys flesus L.) in the Åland Islands, SW Finland. Mem. Soc. Fauna Flora Fenn., 77(1-2), 5-11.

Voigt, H.-R., Wiklund, T. \& Bylund, G. 1994. Mercury in flounder (Platichthys flesus L.) from Finnish coastal waters. $B M B$ (Baltic Marine Biologists) Publ., 15, 117-119.

Voipio, A., Erkomaa, K., Karppanen, E., Mäkinen, I. \& Tervo, V. 1977. Eräiden raskaiden metallien ja orgaanoklooriyhdisteiden pitoisuudet Itämeren kaloissa ja pohjaeläimissä. Ympäristö Terveys, 8(2), 127-143.

Ympäristö. 1998. Silakan elohopeapitoisuudet Suomen merialueella vuosina 1980-1997. Ympäristö, 12(7), 24.

Ympäristö. 2001. Silakan elohopeapitoisuudet Suomen merialueella vuosina 1980-2000. Ympäristö, 15(7), 24. 


\title{
Elavhõbeda ja kaadmiumi sisaldus Soome lahe Soome ja Eesti rannikumerest püütud kalades
}

\author{
Heinz-Rudolf Voigt
}

On võrreldud kaadmiumi ja elavhõbeda sisaldust Soome ja Eesti rannikumere kalades. Vaatluse all oli üksteist kalaliiki, tuntumatest räim (Clupea harengus membras L.), kilu (Sprattus sprattus sprattus L.) ja ahven (Perca fluviatilis L.). Uurimispiirkondadeks, kust kalad püüti, valiti Soomes Tvärminne arhipelaagi ja Helsinki rannikumeri ning Eestis Muuga, Käsmu ja Kunda laht.

Elavhõbeda sisaldus lihaskoes, maksas ja gonaadides oli kõrgeim röövkaladel. Analüüsid näitasid kaadmiumi suurt sisaldust Tvärminne arhipelaagist püütud kaladest lesta (Platichthys flesus L.), räime ja ahvena maksas ning Muuga lahest püütud emakala (Zoarces viviparus L.) maksas. Praegusel ajal jääb nii Soome kui ka Eesti rannikumerest püütud kalade elavhõbeda ja kaadmiumi sisaldus (välja arvatud mõned erandid) allapoole nende riikide ja Euroopa Liidu kehtestatud norme, mille puhul toksikantide hulk toidus ei kutsu inimesel esile haigusnähte. 